https://helda.helsinki.fi

\title{
The interactional emergence of conditional clauses as directives: constructions, trajectories and sequences of actions
}

\section{Lindström, Jan Krister}

$2016-10-28$

Lindström , J K , Lindholm , C C \& Laury , R H 2016 , ' The interactional emergence of conditional clauses as directives: constructions, trajectories and sequences of actions ' , Language Sciences, vol. 58 , pp. 8-21 . https://doi.org/10.1016/j.langsci.2016.02.008

http://hdl.handle.net/10138/234483

https://doi.org/10.1016/j.langsci.2016.02.008

cc_by_nc_nd

acceptedVersion

Downloaded from Helda, University of Helsinki institutional repository.

This is an electronic reprint of the original article.

This reprint may differ from the original in pagination and typographic detail.

Please cite the original version. 


\title{
The interactional emergence of conditional clauses as directives: Constructions, trajectories and sequences of actions
}

\author{
Jan Lindström, Camilla Lindholm and Ritva Laury
}

\begin{abstract}
This article concerns the sequential emergence of Finnish and Swedish insubordinated jos and om 'if' adverbial clauses in interaction from a synchronic, online use perspective. The authors first demonstrate that such clauses function as complete directives without any main clauses, and that recipients treat them as such, responding to the directive as soon as the insubordinate clause is produced. It is then shown that many insubordinated conditionals used as directives (ICDs) are associated with a certain orderly sequential pattern organized in adjacency pairs, which bears a certain similarity to bona fide conditional clauses. This suggests that conditional clause patterns, including insubordinated ones, emerge in interaction in response to actions done and not done by the recipients of the requests, and are thus a product of the interaction of participants in conversation.
\end{abstract}

\section{Keywords}

Social interaction, insubordination, directive actions, conditionals, online syntax, emergent grammar

\section{Introduction}

Adverbial clauses are ordinarily thought to form part of a clause combination and therefore, like other subordinate clause types, to project a superordinate clause to follow if produced in an initial utterance position (see, e.g., Auer, 2005). That is, once an initial adverbial clause is produced, participants in a conversation would, based on their experience with the language, expect a superordinate clause to be produced to complete a "full" complex sentence. However, it is also known that in many languages, clause types ordinarily considered subordinate can, in some contexts, appear without what can be analyzed as superordinate clauses, and thus are non-projecting (e.g. Matihaldi, 1979; Ford, 1993; Clancy et al., 1997; Kauppinen, 1998; Suzuki, 2009; D'Hertefelt, 2015; Sansiñena et al., 2015). Evans (2007) has introduced the concept "insubordination" to refer to (the diachronic development towards) syntactically independent uses of constructions that may have the basic appearance of subordinated constructions such as complement and conditional clauses. However, some of Evans' claims concerning the diachronic pathway towards insubordination have been disputed (cf. Mithun, 2008).

According to Evans (2007), it is crosslinguistically common that conditional clauses (i.e. if clauses) are used without any superordinate clauses to make requests and offers and to express wishes - these are uses which he terms "if requests", "if wishes" and "if offers" (2007, p. 372). The Finnish and Swedish jos and om clauses, the topic of this article, are one example of this kind of insubordination. In spoken interaction, they mostly communicate different kinds of directive actions, but these 
uses are insufficiently (if at all) treated in reference grammars. In addition, there is a wealth of traditionally recognized (but not necessarily commonly used), fully conventionalized insubordinate conditionals which express unaddressed potential or irreal wishes (Om hon bara kommer dit i tid! 'If she only comes there in time'; Om $d u$ var här 'If you (only) were here') or counterfactual expressive meaning (Hade jag bara varit där! 'If I only had been there'). ${ }^{1}$ Finnish also has such uses, cf. Jos se vaan tulee ajoissa 'If s/he only comes in time'; Oi jospa oisin saanut olla mukana 'If only I had been able to be there', from a children's song.

In what follows, we will first give an overview of Finnish and Swedish insubordinate conditionals used as directives (ICDs), building on our prior work on these constructions and leaving aside unaddressed desiderative uses (Laury, 2012; Laury et al., 2013). We will then discuss the interactional emergence of ICDs in conversational sequences. We will demonstrate that they are associated with an orderly sequential pattern organized in adjacency pairs, and that this pattern bears a certain similarity to the emergence of ordinary initial conditional clauses which are followed by a consequent (apodosis) in an orderly fashion. Hence, the ultimate realization of an insubordinate conditional clause or a more canonical conditional clause combination has an interactional trajectory which is dependent on local sequential contingencies involving collaborative input from the participants (cf. Ford, 2004). Interactional approaches to insubordination are not commonplace, but we note the "dyadically dependent" analysis of insubordinate complement clauses that has been put forward by Sansiñena et al. (2015); their investigation looks for a motivation for insubordination in the preceding sequential context, arguing for that an insubordinate clausal unit could be seen as a projection (and completion) of a matrix clausal unit produced in a prior turn (thus "depending" on it). Our analysis, on the contrary, is concerned with projections and actions following a (potentially) insubordinate clausal unit which seems to lack a projected superordinate unit (and thus, completion). We also want to stress that our analysis is strictly synchronic, based on an online syntactical view of utterances and constructions emerging in talk-in-interaction here and now (cf. Auer, 2005); we therefore refrain from making any assumptions about the diachronic emergence of insubordinate conditional clauses.

\section{Data and method}

The data used for the study come from the conversation archives of the Department of Finnish, Finno-Ugrian and Scandinavian Studies at the University of Helsinki. The data include approximately seven hours of Finnish everyday faceto-face conversations and telephone calls among friends, family members and acquaintances and 61 hours of Swedish face-to-face conversations of which most were recorded in institutional settings, i.e. doctor-patient consultations or moderated conversations with high school students. Recordings of both Sweden Swedish (48 hours) and Finland Swedish (13 hours) are included. Taken together, our data contain 42 insubordinated Finnish conditional jos clauses and 92 insubordinated Swedish conditional om clauses, i.e. conditional clauses which do

\footnotetext{
${ }^{1}$ For a fuller account on different functional categories of insubordinate conditional and complement clauses in Germanic languages (including Swedish), see D’Hertefelt, 2015.
} 
not form a clear-cut biclausal construction with a main clause (apodosis). ${ }^{2}$ We have augmented this collection with a few relevant extracts from previous published work on language and interaction such as Lindström (1999).

The analytic methods are rooted in the traditions of Conversation Analysis and Interactional Linguistics (see Couper-Kuhlen \& Selting, 2001). We thus pay special attention to the sequential, turn-by-turn emergence of speaker contributions and their grammatical shaping in conversational interaction as it is unfolding in real time.

\section{Insubordinated conditionals as stand-alone directives}

In general, conditionals function to name hypothetical or irrealis events or states of affairs (Couper-Kuhlen \& Thompson, 2009), which may be presented as either undesirable or desirable by the speaker. The content of the conditional clause is thus unassertable (cf. Dancygier, 1998, p. 23). The sense of "optionality" expressed by conditionals is also mentioned by Ford (1993) as a feature of English if clauses, which makes conditionals useful for offers without any explicating main clauses. Further, Kangasharju (1991, p. 152) found that many of the requests and suggestions in her Finnish data from business negotiations involved conditionality, and she suggests that such uses may give the addressees room for negotiation. Sorjonen et al. (2009, p. 109), on the other hand, found that the conditional was used in requests made at convenience stores to propose actions which were contingent on the acceptance of the recipient of the request; clients used conditional requests for items from clerks when the clerk had access to the item, and the client did not.

Conditional clauses are initially marked with the subordinator om in Swedish and jos in Finnish, both corresponding to if in English. In a canonical view, the conditional clause is an adverbial clause which does not alone express an action (and thus, cannot stand alone); instead, it is combined with a superordinate (or matrix) clause which signifies the actual type of action, e.g. a question or a directive (Teleman et al., 1999, p. 475), or expresses the condition under which the consequent in the main clause can be realized (Hakulinen et al., 2004, §1114). Swedish conditional clauses display typical features of subordinate clauses (with a SVO structure and sentence adverbs, including the negator, before the finite verb) and allow the use of the modal auxiliary skulle 'would' only in special cases (Teleman et al., 1999, p. 646). In Finnish, conditional jos-clauses are considered subordinate adverbial clauses integrated into their main clause, but they do not differ from main clauses in terms of word order or other syntactic features. Finnish has a morphological conditional, which can freely occur in jos-clauses as well (see, e.g., Excerpt 2 below). However, insubordinate conditional clauses are not uncommon in spoken Finnish and Swedish (e.g. Kauppinen, 1998; Laury, 2012;

\footnotetext{
${ }^{2}$ These figures seem to suggest that insubordinate conditional clauses are much more frequent in Finnish than in Swedish. We believe, though, that the difference depends on the types of data we had available: insubordinate conditionals are especially frequent in the Finnish telephone calls, most of which involved planning of future actions. The construction is used to a lesser degree in casual group conversations, a genre dominating the Swedish dataset, in which most of the talk is about specific topics and not so much about actions which should be carried out. Hence, the activity type is probably crucial for the directive use of insubordinate conditionals.
} 
Laury et al., 2013; D'Hertefelt, 2015); in such uses, they also retain the basic internal syntactical features of a typical conditional clause.

In our Finnish and Swedish data, the insubordinated conditional clauses function most commonly as directives in the sense of Ervin-Tripp (1976), i.e. to communicate actions which are designed to get someone to do something. More specifically, out of the 134 instantiations in our data, 79 expressed suggestions, requests and proposals, usually concerned with future action: in a suggestion, the agent as well as the beneficiary is Other, in a request, the agent is Other and the beneficiary is Self, in a proposal, both Self and Other are agents and beneficiaries (for this categorization of actions, see Couper-Kuhlen, 2014). ${ }^{3}$ Example (1), taken from a private telephone conversation, illustrates the use of a Swedish om clause for a request.

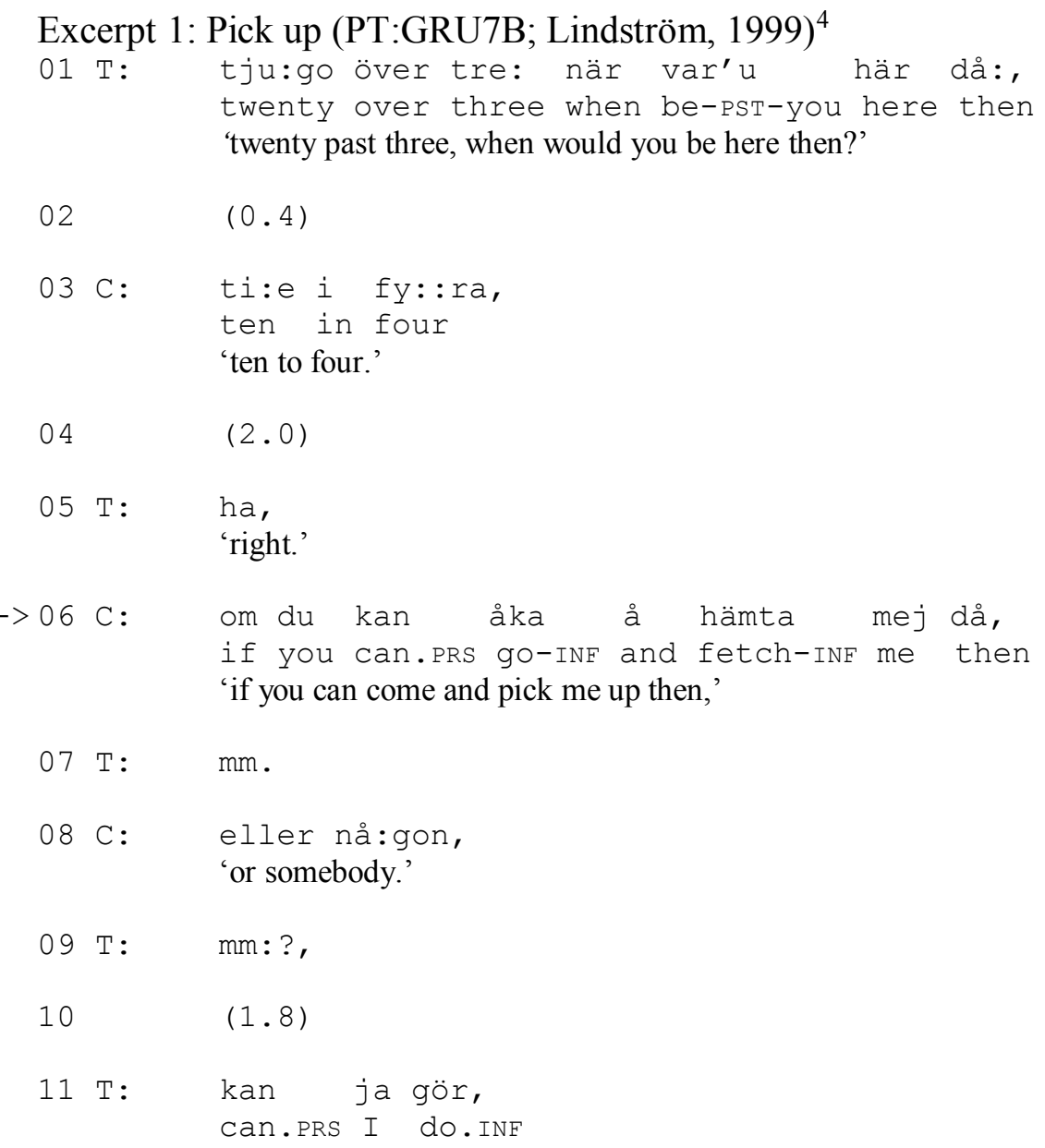

\footnotetext{
${ }^{3}$ The independent jos and om clauses which were not categorized as clearly expressing requests, suggestions or proposals fall into suppositions (jos ne on epähygienisiä '(what) if they are unhygienic'), into metapragmatic uses, for example signaling a shift in the phase of the conversation (om vi nu drar nån slutsats av de här 'if we now draw some kind of conclusion of this'), or to uses which seem indeterminate between a proposal, question or a metapragmatic expression, for example when the doctor examines the patient and says om ja trycker här 'if I press here'; the doctor seems to both inform the patient of what he is going to do and expects the patient to say how the (sore) point that was pressed felt.

${ }^{4}$ The transcripts follow general guidelines for a CA-notation, see Ochs et al., 1996, pp. 461-465 and the Appendix in this paper.
} 
$12 \mathrm{C}: \mathrm{mm}:$

Prior to the extract, Cajsa has informed Tore that she intends to take the 3:20 train to the town where Tore lives. Tore confirms the time in 1.01 and continues on to ask when the train arrives. Having informed about the arrival time, Cajsa (in 1. 06) requests Tore ("or somebody") to pick her up. This request is formulated with an independent conditional om clause, which then is followed by an action granting by Tore in 1. 09-11.

This request-granting sequence shows that the om clause in 1.06 is treated as a complete unit. However, the interactional meaning of the conditional directive is negotiated in the ensuing sequence. Tore responds to the conditional (1.06) in an interactionally non-committal manner with the recognitional token $\mathrm{mm}$ in 1.07 . Cajsa then continues on to pursue a clearer response and produces the increment "or somebody" in 1. 08. Note that she does not produce any consequence clause or another explanation: for her, the conditional directive form is the full-fledged action form. Since Tore is not immediately responding (there is also a pause in 1. 10), he may be oriented to some form of continuation from Cajsa. When this does not follow, he draws the consequences and formulates an explicit granting of the request in 1.11 which brings this request-granting sequence to a closure.

The Finnish jos clauses used as directives fall into several classes based on the target of the directive (Laury, 2012; cf. Ahrenberg, 1987); that is, they are formatted differently depending on the intended doer of the action proposed. If the directive is person-marked in the second person, rather unsurprisingly it expresses an action intended to involve an action by the addressee, and it is also responded to by him or her. The verb in such requests is often in the conditional mood. Consider example (2) below. It comes from a telephone conversation where the participants are discussing plans for the upcoming purchase of a gift for a friend.

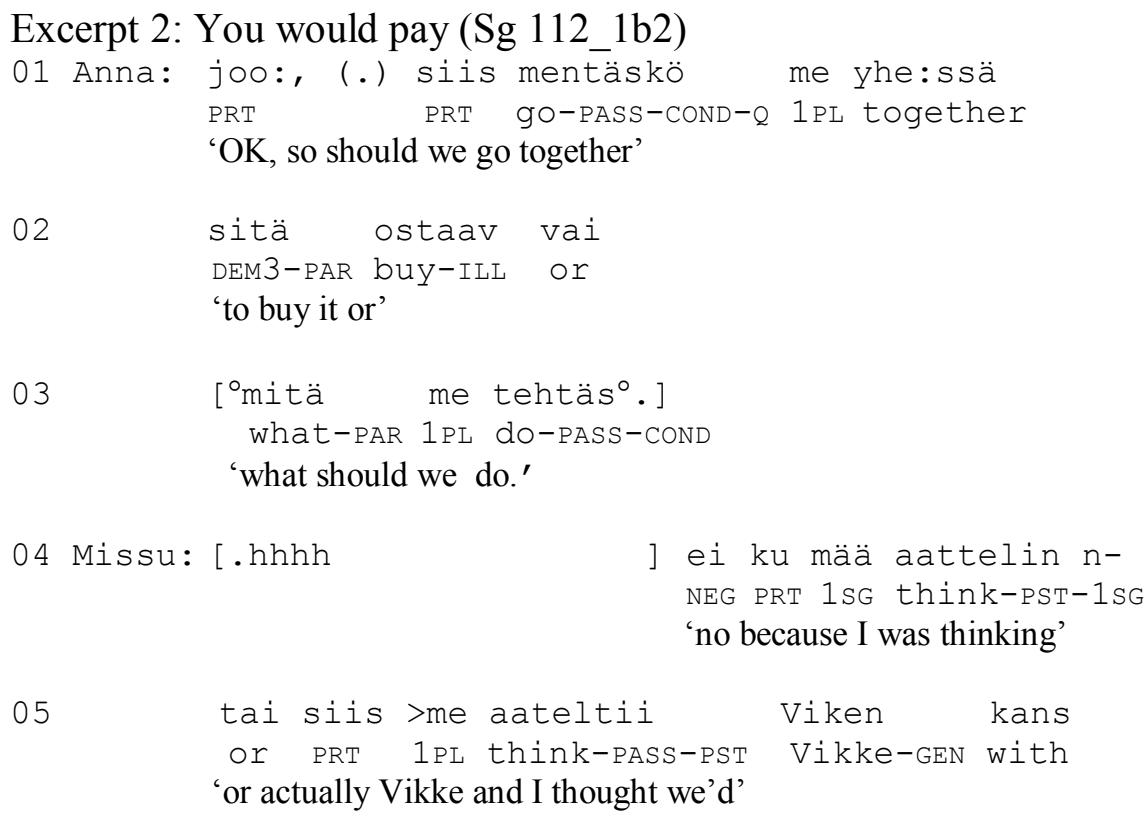




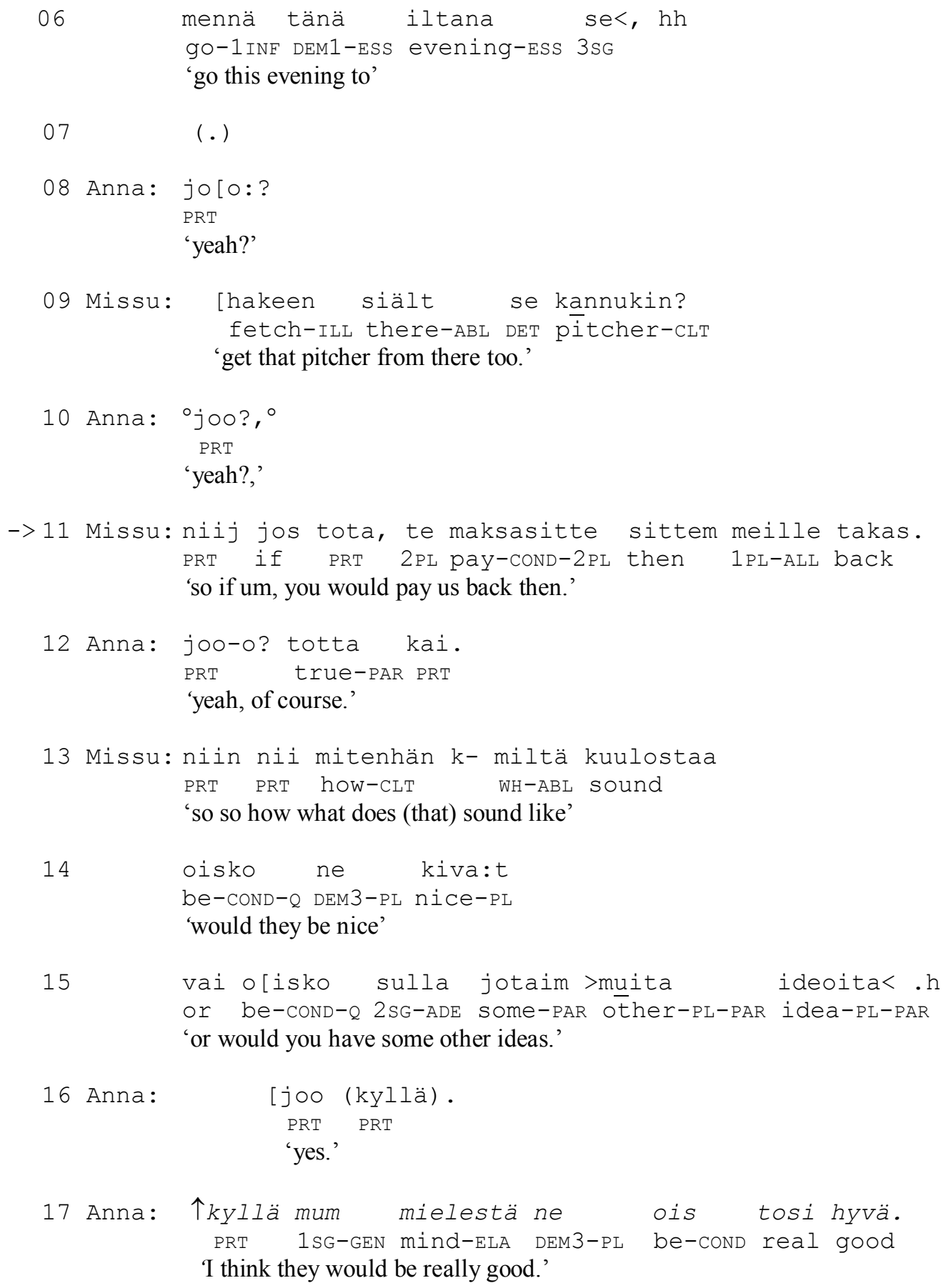

Anna proposes in 1. 01 that she and Missu go together to purchase the planned gift. Missu reveals that she is already planning to go with another person named Vikke (1. 04-06 and 09). In 1. 08 and 10, Anna responds to Missu's proposed plan with the particle joo 'ok, yeah', which can be taken as indicating that she has registered and understood the plan (Sorjonen, 2001a; b). In 1. 11, Missu continues on to another action (see Hakulinen \& Sorjonen, 2009 on joo as closing implicative) and requests that Anna (and some other unspecified person or persons) pay her and Vikke back for her share once they got the gift. The request is formatted with a jos clause. In the jos-clause, there is a separate second person plural pronoun, te, and the verb maksa-isi-tte 'pay-COND-2PL' is in the second person plural conditional 
form. The turn ends with utterance-final prosody. Anna responds immediately and affirmatively to the request with joo, followed with a reinforcing adverbial totta kai 'of course' (on joo as a compliant response to directives, see Sorjonen, 2001a, pp. 95-118). In our Finnish data, the jos directives formatted in the second person are answered immediately after the request is completed, and the participants do not seem to be waiting for a niin 'so' consequent to be produced.

The previous excerpts have shown that Swedish and Finnish insubordinated om and jos clauses can be used for requests. As we will now demonstrate, there are also cases in our data where they are used for proposals for joint action. The next example illustrates this use from the Finnish data. If a joint action by the speaker and co-participant(s) is proposed, a passive form is used. The Finnish passive always implies human agency, and it is the verb form commonly used in the first person plural in spoken varieties of Finnish, ordinarily with a separate pronoun (see, e.g., Shore, 1986; Helasvuo, 2006). The passive verb of the jos directive may be in the indicative form, as in this example, or, more commonly, in conditional form. These ICDs are also responded to by the other participants immediately after the proposal is made. The response may take various forms, such as a conditional verb repeat, as in excerpt (3) from a telephone conversation between two friends, Missu and Kaaka. In an earlier call the same day, the participants have discussed plans to go out for a drive (see Excerpt 6 below). Kaaka is now calling to tell Missu that the car isn't available and the plans therefore won't work out.

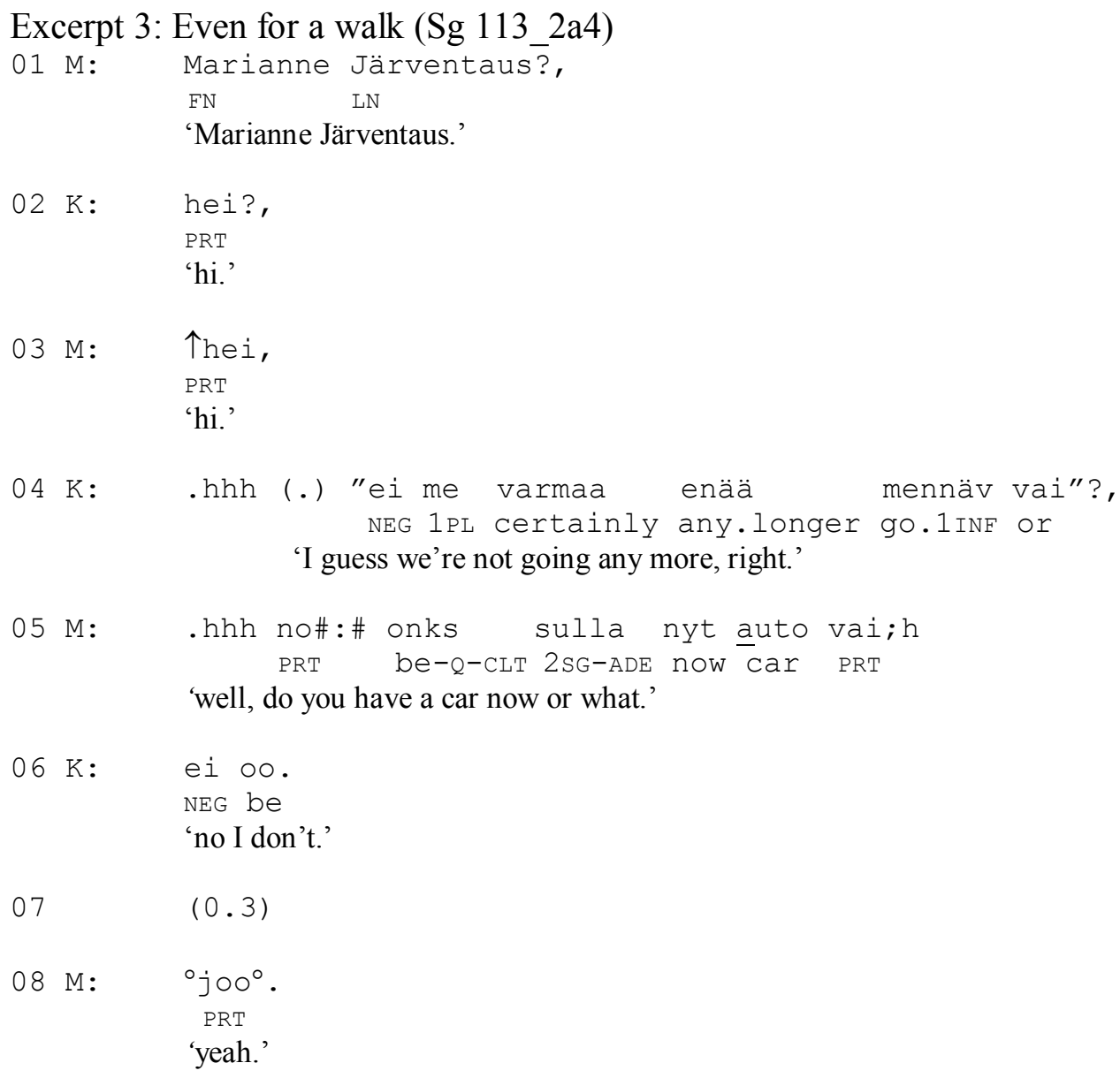




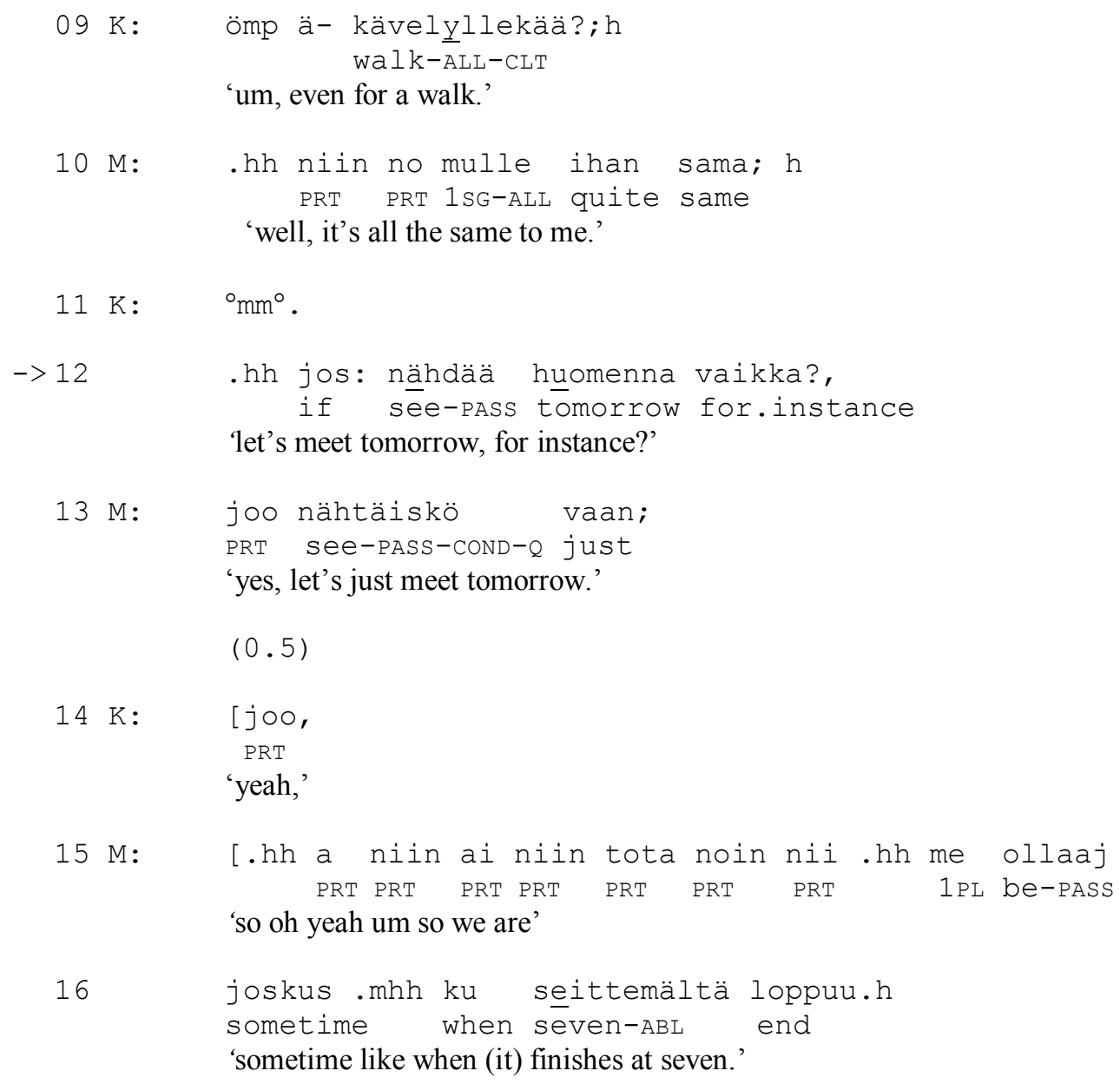

As in examples (1) and (2), the directive expressed by the conditional clause is embedded in a negotiation regarding planning for future activities. In this example, after the greeting sequence, the participants establish that they will not be able to go for a drive or even for a walk that evening (1. 04-10). Kaaka then produces a jos clause in 1. 12, which functions to propose that she and Missu see each other the next day. In her jos clause, Kaaka uses the conventional form for first person plural reference, the passive form of the verb nähdä 'to see', but, as is conventional with jos clauses used as first person plural directives, there is no separate pronoun. Missu responds to this immediately in the affirmative (1. 13), using joo, indexing compliance with the directive (Sorjonen, 2001a, pp. 95-118) and a verb repeat, but now in the conditional form. This makes the compliance still negotiable and somewhat open. The participants then go on to negotiate the time to meet the next day.

In our Swedish data, the most typical form of insubordinated om clauses involves a present indicative form of the verb and a second person address, as in example (1) above. ${ }^{5}$ With the format $o m+d u+$ indicative, an action by the co-participant is

\footnotetext{
${ }^{5}$ In some situations, the doer of the designated action may be left open with the use of the generic third person pronoun man 'one': om man rör så här 'if one moves (the arm) like this' (see Laury et al., 2013). Past tense is conventionally used in Swedish conditionals expressing an irrealis meaning and pluperfect in counterfactuals; however, these verb forms do not occur in the present collection of ICDs.
} 
urged. A joint action is proposed with the use of the first person plural pronoun $v i$ 'we', as shown in extract (4), 1. 04, which is from a medical consultation. Here the doctor (D) is showing the patient where she and the doctor himself should sit during the consultation.

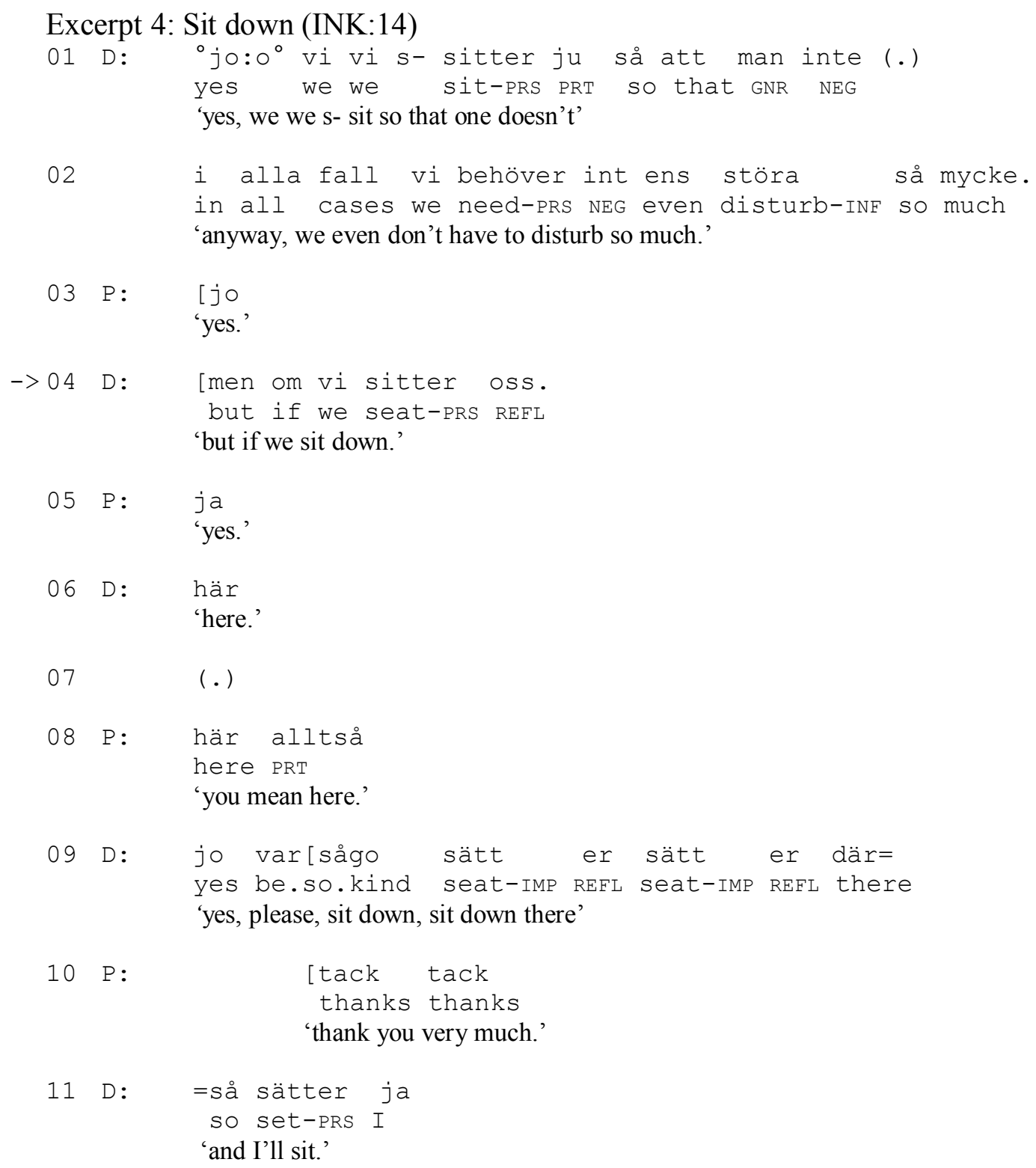

At the beginning, the doctor refers to the arrangements for the video recording in the physical room prior to the consultation proper. The move into the consultation is signalled by the collectively formulated directive to sit down, to which the patient complies in 1.05 . This is followed by a few turns where the parties' exact seating is negotiated.

In sum, the ICDs have their home environment in contexts where future action - who is to do what - is being negotiated; at the same time, they may also refer to actions 'here and now', as seen in excerpt (4). Insubordinated conditionals are functionally conventionalized and are responded to by participants in ways which 
show that they interpret them as full-fledged directives. The response ordinarily follows immediately after the directive move is made, indicating that the conditional clauses are not expected by participants to be followed by consequents. Therefore, these constructions should not be analysed as formally incomplete (cf. Chevalier, 2008 on incomplete utterances in French conversation.)

However, owing to local sequential contingencies, the directive sequence may, nonetheless, develop in ways in which a possibly free-standing conditional directive is followed by an elaboration in the form of something that may look like a consequent clause. The interactional emergence of such conditional directive sequences is the topic of the following section.

\section{The interactional emergence of Finnish and Swedish jos and $o m$ directives}

When analyzing our data, we observed that insubordinated conditionals are not "free-standing" units in an absolute sense but instead, they are situated in an interactional trajectory which may involve several dialogical moves by the participants. ICDs commonly emerge in conversation after a preface, which may or may not be receipted by the addressee (if addressed, we get a pre-sequence). The preface or pre-sequence is then followed by a request, proposal or suggestion, which is complied with (or explicitly not complied with) by the recipient. There may also be an account produced by the same person as the ICD, which may directly follow the request or come after the recipient's compliance. Moreover, some of these accounts may appear to have a consecutive relation to the preceding conditional. The account may be acknowledged by the recipient, or, if the account comes in the same turn as the directive, it may simply be followed by the compliance turn. Figure 1 below illustrates the components of this sequential organization in schematized form with designated slots for a pre-sequence, directive sequence and motivation sequence ( $\mathrm{A}$ and $\mathrm{B}$ represent the interactants).

\begin{tabular}{|ll|}
\hline Pre-sequence & $\begin{array}{l}\text { A: Preface } \\
\text { (B: Receipt) }\end{array}$ \\
Directive sequence & A: ICD (request, proposal or suggestion) \\
& $\begin{array}{l}\text { (B: Receipt/compliance [or in the next slot]) } \\
\text { A: Account } \\
\text { (B: Receipt/compliance [if not in the prior slot]) }\end{array}$ \\
\hline
\end{tabular}

Figure 1. Schematized format of the directive sequence done with ICDs.

An interactional trajectory of this kind can be observed in excerpt (5), which comes from our Swedish data, an everyday audio recording of a gathering of elderly women friends. The hostess, Ada in the transcript, first proposes that the participants sit down at the table, and then suggests that one of the guests, Beda, sit down in a particular chair (1.08).

\footnotetext{
Excerpt 5: Better chairs (GRIS_SÅINF:2:1) 01 Ada: $\begin{gathered}\text { att } e: h . h h \begin{array}{c}\text { hörni, mina vä:nner?, } \\ \text { that }\end{array} \text { PRT } \\ \text { my-PL friend-PL }\end{gathered}$
} 
'=so um .hh look, my friends?'

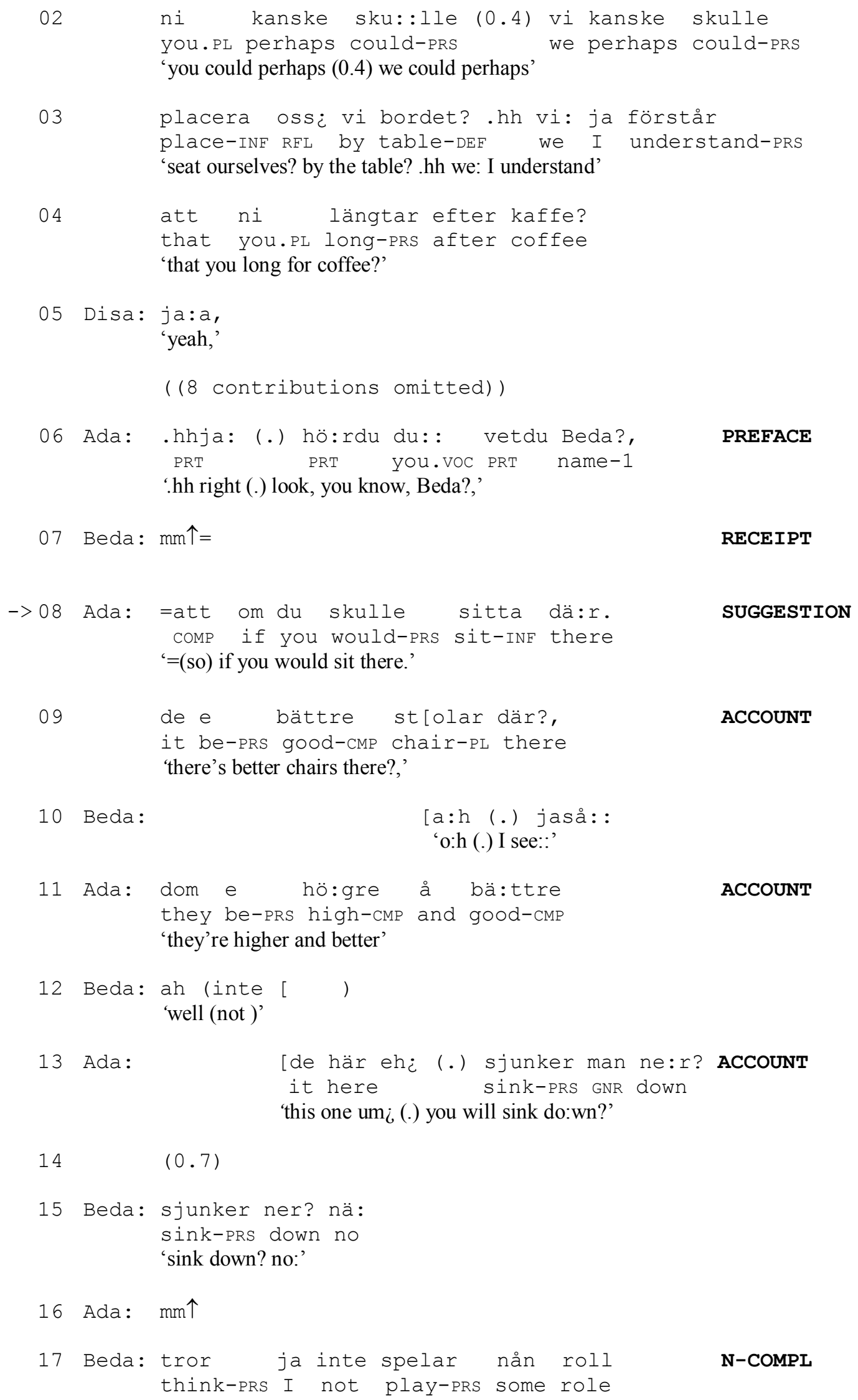


'I don't think it makes any difference'

18 Ada: ah ja, du får sitta som du vi:ll (0.5)

PRT PRT you may-PRS sit-INF as you want-PRS

'oh well, you may sit as you like' $(0.5)$

19

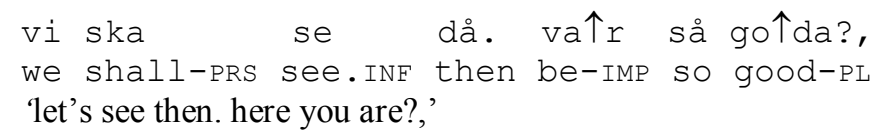

The ICD sequence in extract (5) is initiated by Ada's pre-announcement (1. 06), to which Beda responds with the go-ahead $\mathrm{mm}$ (1. 07). In 1. 08, Ada continues to the ICD, asking Beda to sit down at a particular place. Various features indicate the potentially dispreferred nature of Ada's suggestion. Firstly, the request is preceded by the pre-sequence in 1. 06-07. Secondly, the conditional clause contains the modal auxiliary verb skulle 'would, should', which possibly contributes to making the action a (more indirect) polite suggestion. The auxiliary is used in conditional clauses only to convey a remote possibility (Teleman et al., 1999, p. 646; cf. Quirk et al., 1985, p. 1093 on the tentative should in English if-clauses). Thirdly, the ICD is not completely freestanding, but immediately followed by an account, indicating that Ada wants Beda to choose another place to sit because the other chairs in the room are more comfortable. Beda responds in 1.10 with the change-of-state token jaså, which has been defined as a token used to indicate uptake without commitment, rather than acceptance (Anward, 1987; Teleman et al., 1999; p. 755; Green-Vänttinen, 2001). This response can, thus, be analyzed as indicating at best rather weak compliance (see also the apparent negation in 1. 12), which obviously causes Ada to continue on by producing two additional accounts for her request (1. $11,13)$. The directive sequence is terminated by a two-step response from Beda, in which she, after a pause, first produces a questioning move (1. 15), and then expresses non-compliance (1. 17) with Ada's previous request which was formulated with an insubordinated conditional clause.

While in the previous example, the suggestion formatted as an om clause was turned down, in the next example (6), taken from our Finnish data, the recipient complies with the directive. This excerpt comes from the beginning of a telephone conversation between two young woman friends, Missu and Kaaka (see Excerpt 3 above). After an initial how-are-you question, Kaaka proposes to Missu that she come for a drive with her (1.06-08).

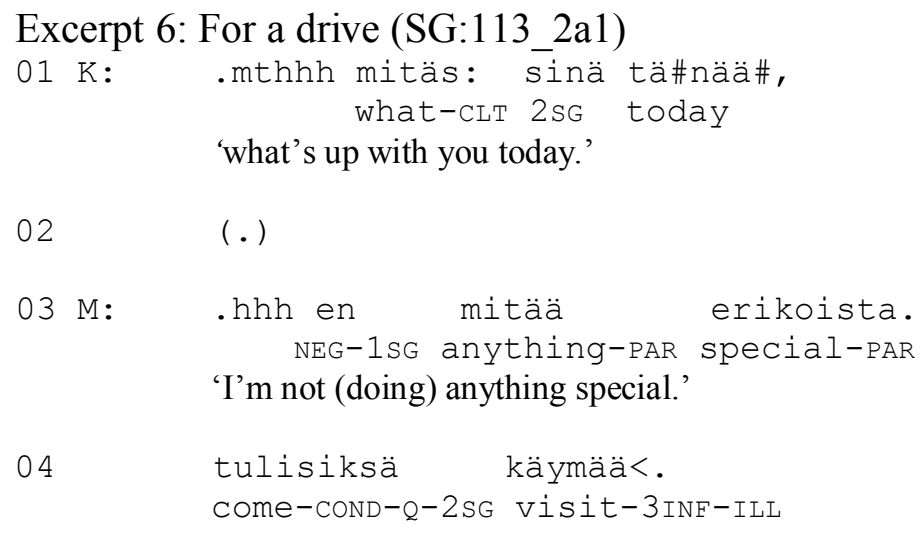


'would you like to come to visit.'

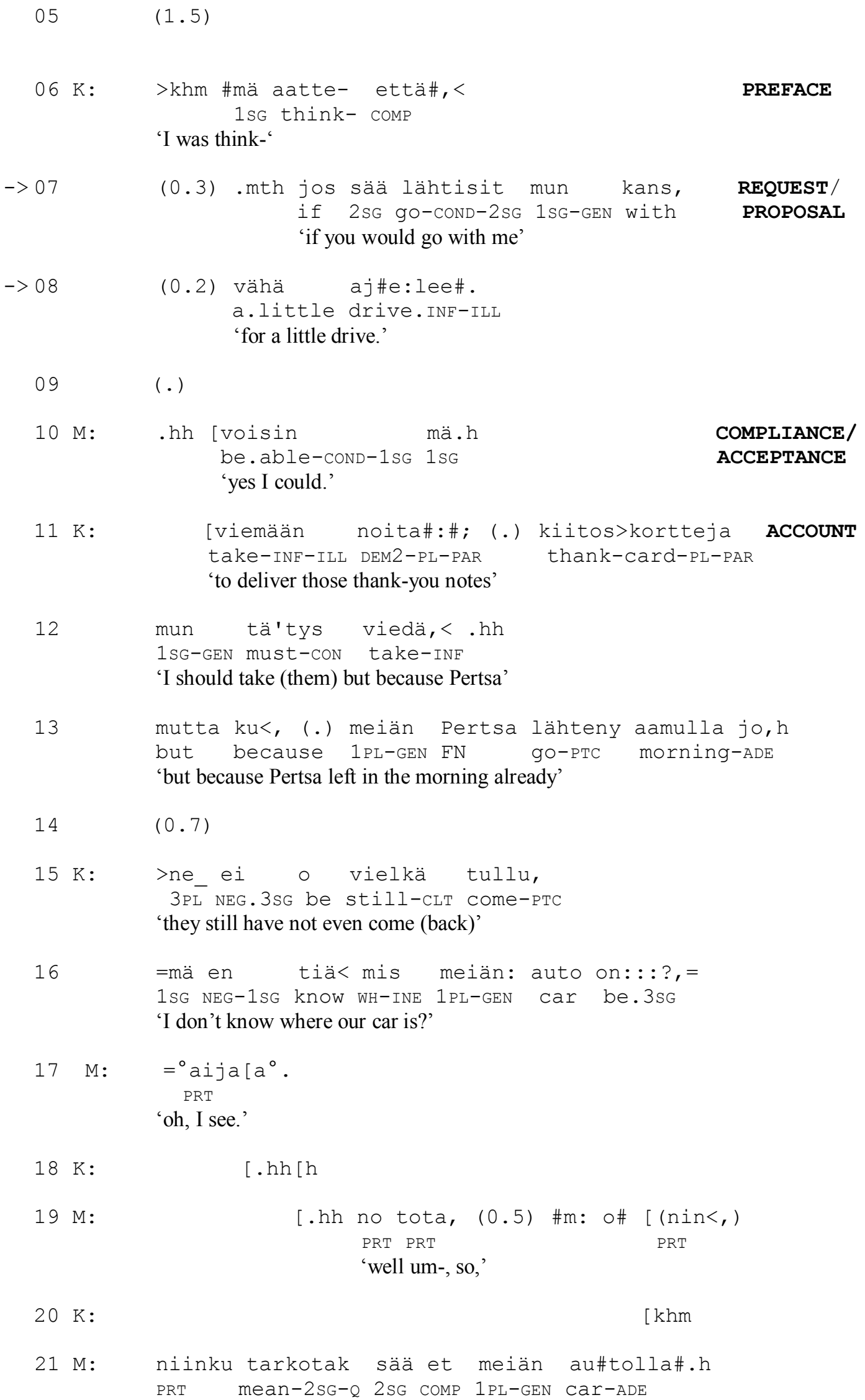


'do you mean like with our car.'

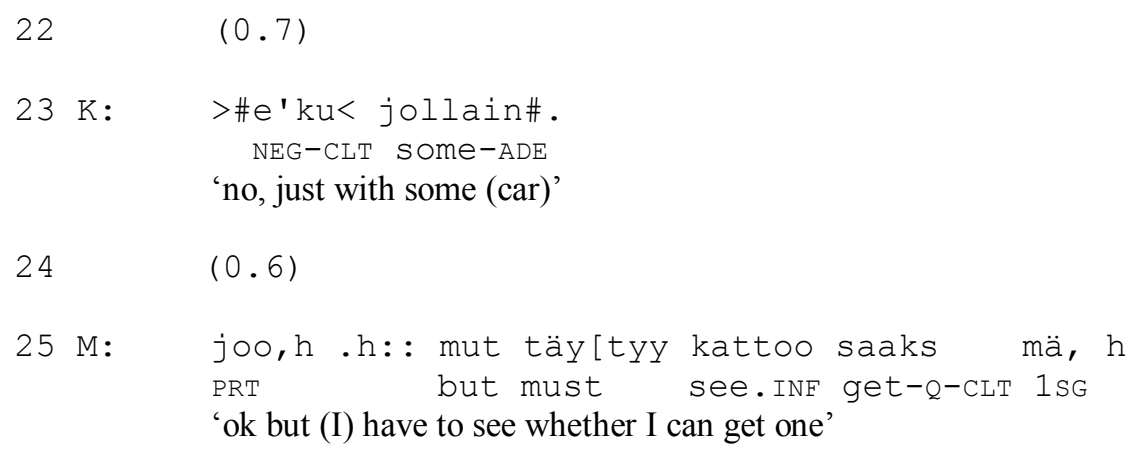

After Kaaka's how-are-you question (1.01), which in retrospect can be analyzed as a preface to a preface, since it asks about Missu's availability, crucial for Kaaka's to-be-discussed plan, Missu, perhaps taking Kaaka's turn as a pre-invitation, next invites Kaaka to come over to her place, pre-empting the projected invitation. Kaaka neither accepts nor declines the invitation, but instead issues a directive formatted as a jos-clause (1. 07-08), which at this point can be understood as a proposal. The ICD is here prefaced by a clause constructing the proposal as a thought (mä aatte- että, 'I was think-'). The practice of framing a proposal as a thought, according to Stevanovic's (2013) study of institutional interaction, can be seen as a way to manage problems in joint decision making. This TCU preface may well be used here to such an effect, given what emerges later; namely, Kaaka's josdirective is not simply a proposal to get together, as can be seen in 1. 11-16. However, this is not yet clear to Missu, who, after a short gap, accepts the proposal (1. 10). Although Missu's acceptance is formatted as an unproblematic one, the short gap before the acceptance may be motivated by and reflect the slightly dispreferred formatting of Kaaka's jos-formatted directive. Namely, besides its construction as a thought, the directive is done with pauses (1. 07 and 08) and with the mitigator $v \ddot{a} h \ddot{a}$ 'a little'.

In overlap with Missu's acceptance of what she at this point may well consider a proposal for joint action (cf. Couper-Kuhlen, 2014 for action labels), Kaaka begins a rather complex account (1. 11-16), which, given the short gap before Missu's acceptance (1.10), could be taken as an increment. Kaaka's prior turn in 1 . 07-08 has been brought to a syntactic and prosodic closure, but 1.11 could be analyzed as being syntactically fitted to her directive ${ }^{6}$. Kaaka explains that she needs to deliver some thank-you notes (1. 11-12), but that someone named Pertsa (a family member, judging from the modifier meiän 'our' preceding the name) has not returned, and she does not know where the family car is (1. 13-16) This is receipted by Missu with aijaa (1. 17) which, according to Koivisto (2015) is a default news receipt often preceding a follow-up question. Here, Missu issues a repair initiator, wondering whether Kaaka had actually requested that they go for a drive in Missu's family's car (1.21). Kaaka equivocates (1.23), and the sequence is brought to a close.

\footnotetext{
${ }^{6}$ Lines 11-12 actually form a pivot construction, where kiitoskortteja 'thank-you notes' can be analyzed as both the object of viemään 'to take' in 1.11 and the object of viedä 'to take' in 1. 12.
} 
So far, we have seen that Finnish and Swedish ICDs emerge in conversation as a result of the collaboration between participants. The directive is commonly prefaced, and the preface may be responded to by the recipient (5). The directive may be a suggestion (5), a request (1) or a proposal for joint action (6). The directive may be directly followed by an account (5), or an account may follow compliance by the recipient (6). On the other hand, the recipient may simply acknowledge the request but not take a stance to compliance until the account is completed (5).

Next we will demonstrate that the pattern of emergence of ICDs can become even more similar to the emergence of bona fide conditional clauses. Excerpt (7) comes from our Swedish data and shows that initial om clauses can occasionally be understood and formatted as either insubordinated conditional clauses doing requests or ordinary initial conditional clauses followed by a consequent clause. The excerpt comes from a conversation between a home care helper $(\mathrm{H})$ and her elderly client $(\mathrm{C})$.

Excerpt 7: Red mat in front of the bathtub (PT:GRU7B; Lindström, 1999)

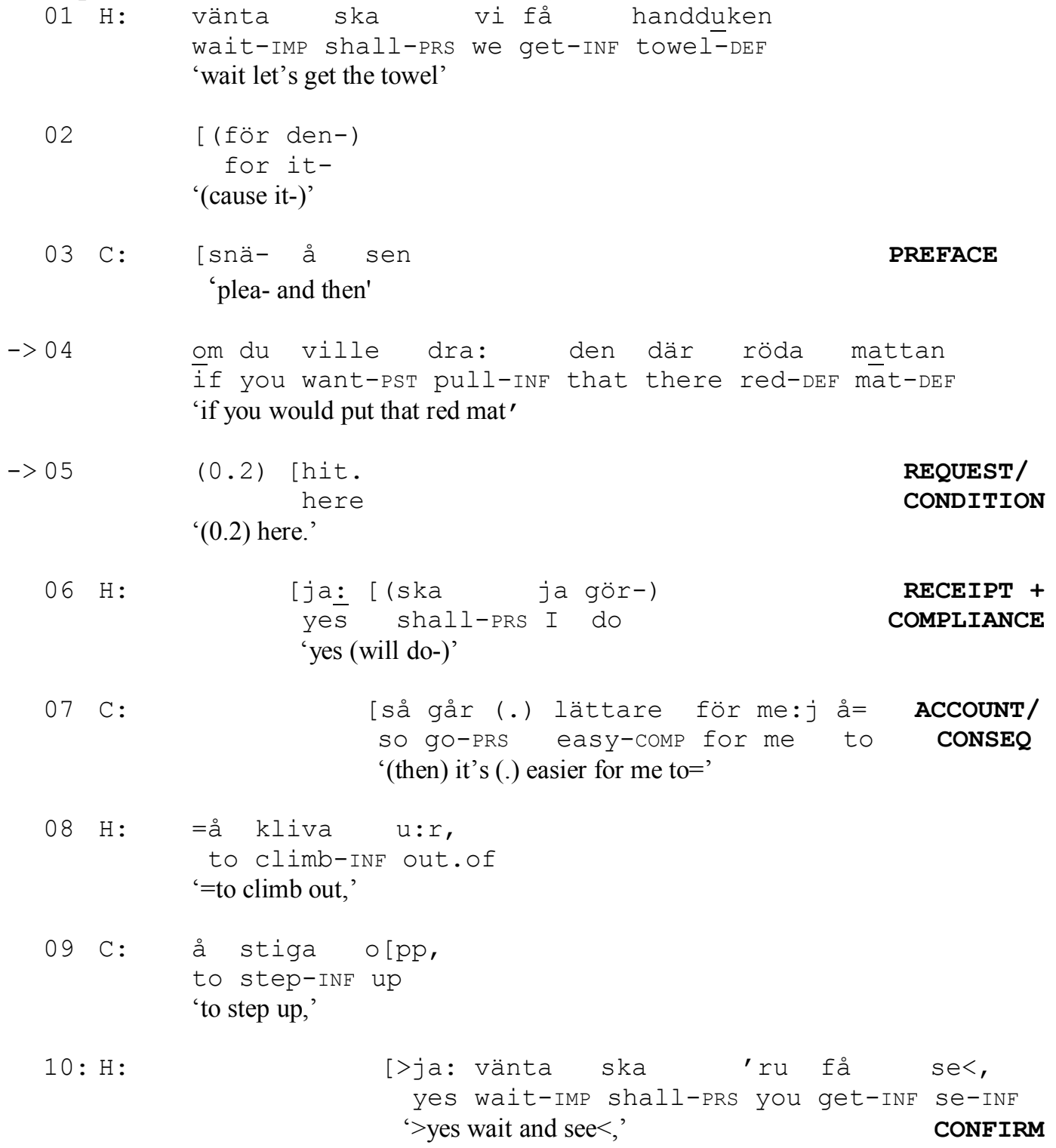


The client's request in 1. 03-05 has the format of a short pre-announcement (snä, which is probably a cut-off of the conventional polite request opener snälla '[could you be so] kind', combined with the transitional unit a sen 'and then') followed by the ICD. The conditional unit has falling intonation in 1.05 , thus signaling potential turn closure. The home care helper treats the conditional as doing request, and produces a response turn consisting of the response token $j a$ ('yes') followed by a clause expressing compliance (1. 06). In overlap already, again, the client initiates an account (1.07), starting with the consecutive adverb så 'so, then', which can also be heard as a consequent to her directive move in a conditional, i.e. as in an 'ifthen' relation. The client's account is syntactically incomplete, and both participants produce following turns (1. 08-09) which are formatted as possible completions of the utterance in 1. 07. As argued by Lindström $(1999$, p. 21$)$, the client's delayed completion (cf. Lerner, 1989) deletes the almost synonymous contribution by the home care helper and emphasizes the client's perspective: the choice of verb in 1.09 depicts someone who is sitting in a bathtub, 1.08 portrays the situation from outside. Finally, the home care helper confirms her compliance verbally in 1.10 .

The next example shows that non-directive, biclausal conditional clause combinations can, indeed, emerge sequentially in a way that closely resembles those we have identified for jos and om clauses as directives. Excerpt (8) comes from a multiparty conversation among young women friends. Susa is strategizing her financial circumstances; she is planning to work for a certain period in order to then quit and collect unemployment benefits.

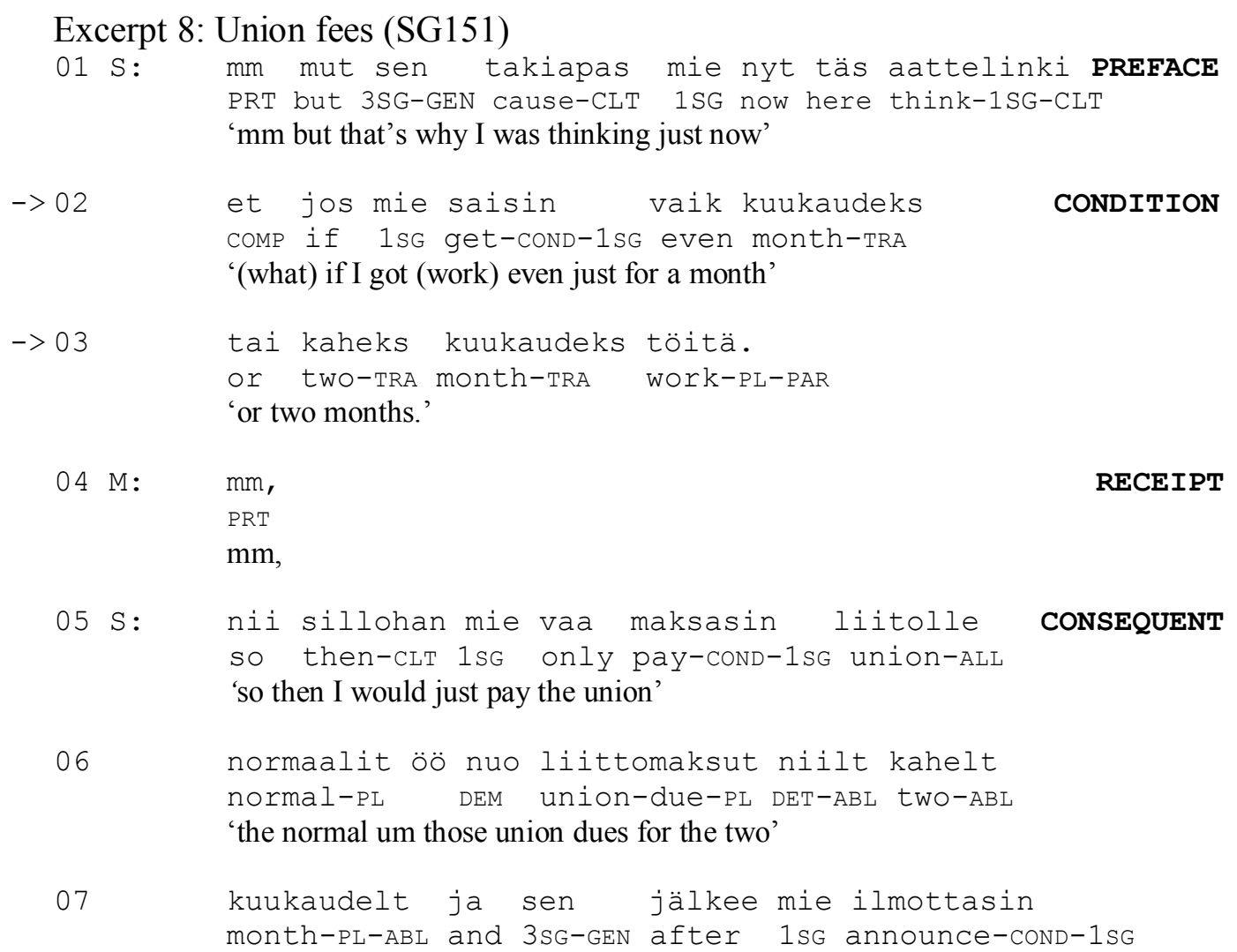


'months and after that I would announce'

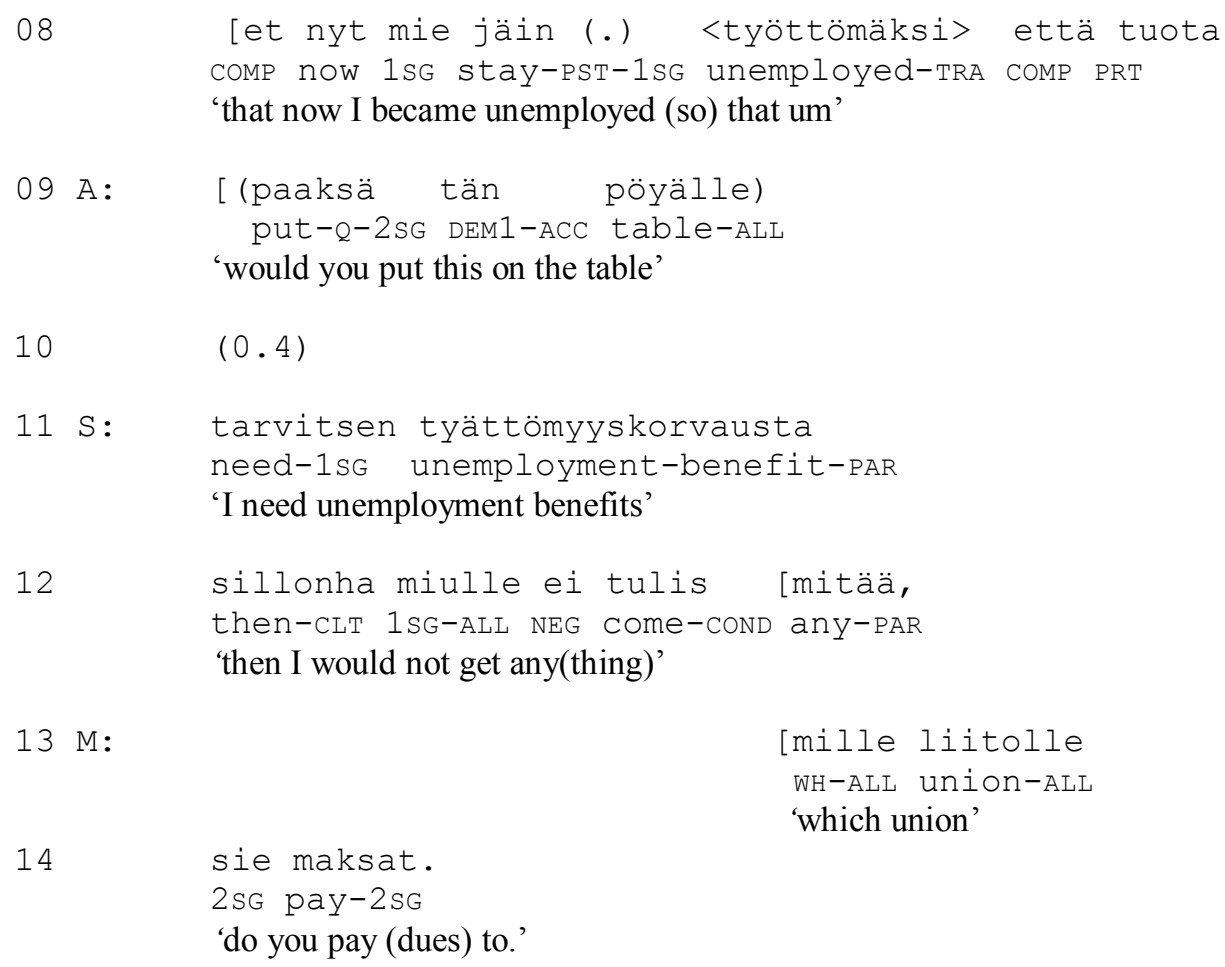

Susa prefaces her initial conditional clause by constructing it as a thought, in a way that is very similar to what was done by Kaaka in our previous Finnish example, excerpt (6). She then goes on to express a condition, expressing a possible future state of affairs, with a jos-clause embedded in the framing clause ${ }^{7}$. She also brings this utterance to a prosodic closure (1.03), in a manner quite similar to the other ICDs in our data. This is receipted by Miia (1.04) and Susa then goes on to express a consequent, formatted as a niin 'so, then' clause (1. 05).

Note that unlike what happens in our preceding Swedish example (7), Susa's jos-clause cannot be interpreted as a directive (or is not treated as such by the other party either). However, it is prefaced in 1.01 (with a formulation as a thought, cf. Excerpt 6), and she still brings her utterance to a prosodic closure at the end of the jos clause. This utterance is then receipted by one of the co-participants. This time, however, it is only after this receipt that Susa goes on to express the consequent, which, in a similar way to accounts following jos and om directives, motivates what is expressed in the conditional: Susa explains that if she gets work for a month or two (hypothetical condition), then she can become unemployed and collect benefits (consequent). The emergence of this jos conditional clause then has features in common with the emergence of ICDs in our data. However, the functional status of

${ }^{7}$ One of the anonymous reviewers found the use of the et complementizer (glossed as COMP) in line 02 confusing. Finnish verbs of cognition, as well as other CTPs, require the use of the complementizer even before direct speech embedded in the framing clause, such as is the case here. This does not show up in the translation because 'I was thinking that what if...' is not idiomatic English. The 'what' addition in parentheses in the free translation expresses the potential of the jos clause to express an (as yet unrealized but possible) state of affairs. This makes the jos-clause similar to those insubordinate but non-directive uses exemplified in section 1. Thus its potential as a protasis is not realized until the utterance in line 05 . 
the two parts in sequences of a conditional and a subsequent clause differ when we compare excerpts (5), (6), (7) and (8), as illustrated in Table 1:

Table 1. A comparison of semantic-pragmatic relations between conditional and subsequent clauses in extracts (5-8)

\begin{tabular}{|c|c|c|}
\hline Ex. & Suggestion & Account \\
\hline \multirow[t]{2}{*}{5} & If you would sit there. & There's better chairs there. \\
\hline & Proposal/request & Account \\
\hline \multirow[t]{2}{*}{6} & If you would go for a drive with me. & I need to deliver thank-you notes \\
\hline & Request & Account/consequence \\
\hline \multirow[t]{2}{*}{7} & If you would put that red mat here. & It's easier for me to step up. \\
\hline & Condition/hypothesis & Consequence \\
\hline 8 & $\begin{array}{l}\text { If I got work even just for a month } \\
\text { or two months. }\end{array}$ & $\begin{array}{l}\text { Then I would just pay the union } \\
\text { those normal union dues for the two } \\
\text { months. }\end{array}$ \\
\hline
\end{tabular}

In (5), the conditional clause stands clearly on its own as a suggestion for the coparticipant to act. The following move accounts for the suggestion but cannot be heard as a consequence of its contents, i.e. the chairs are not better if the recipient of the suggestion sits on them. The conditional in (6) is formatted as dispreferred, but receipted by the other party as a proposal and complied with. In overlap with the compliance turn, the ICD is followed by a rather complex account which reveals that the ICD was actually a request; however, this account cannot be easily understood as a consequent either, although here, it turns out, the delivering of the thank-you notes is, in fact, conditional on the requestee providing her car. The conditional in (7) clearly expresses a request of an action which is followed by a motivation of it through a description of the consequences of the action when carried out. This account has therefore a consecutive relation to the preceding move: 'if you do x, then I can do y', but the realization of the consequence does not seem semantically necessary here as it is not in (5) either. In fact, its function may be to foreground the client's need of help and the home care helper's responsibility to provide help of this kind. This is different from (6), where the account(s) are necessary to resolve the ambiguity of the ICD turn, which turns out not to be a proposal for joint action but actually a request. Finally, in (8), the conditional clause does not express a directive at all but formulates a hypothesis of a future state of affairs. The formulation of the consequence is necessary because the conditional, as an adverbial clause, only delivers a background for the situation which is depicted in the conditional clause combination. To take an interactional angle to this, the consequence is not implicated clearly enough in cases like (8), and this contingency makes a continuation with an explicating consequent necessary.

In this section of the paper we have shown that insubordinate jos and om requests emerge in conversation in a sequence which bears a close resemblance to ordinary 'if-then' sequences consisting of a protasis (expressing a condition) and an apodosis (expressing a consequence). Both the former and the latter are commonly prefaced, and the preface may be responded to by the recipient, resulting in a presequence. The conditional clause expressing a suggestion, a request, a proposal for joint action, or simply a condition then follows, and may be receipted verbally by the other participant. In the case of a directive, the receipt expresses compliance, 
while in the case of a conditional, it expresses an understanding of the conditional relation. What follows then is interpretable as an account, or, in the case of biclausal conditional constructions, as a consequent, but as shown, the account can also be interpretable as a consequence of compliance with the action requested, as in our Excerpt (7). If the compliance is delayed (Excerpt 6), the account may follow the directive immediately. The ubiquitous occurrence of accounts is probably a function of the generally dispreferred nature of many directive actions, which is relative to the recipient's entitlement to comply (see Curl \& Drew, 2008). We have accordingly noted that many ICD turns are designed as dispreferred, containing pauses, mitigations and markers of indirectness (cf. Pomerantz, 1984). On the other hand, if the compliance is immediate and unproblematic (Excerpts 3, 4), there may be no account at all. All in all, we see that both insubordinated directives and ordinary conditional-consequent clause combinations emerge on-line, as collaborative actions of the participant issuing the directive or expressing a condition, and their addressees, and in response to the actions performed by both participants (cf. Ford, 2004). Such co-activity, which involves recognition of upcoming interactional trajectories, builds on intersubjectivity, a sufficient level of shared understanding between the interactants (cf. Schütz, 1953, pp. 11-12; Linell, 2014).

\section{Conclusions}

In this article, we have discussed the use of insubordinated conditional jos and om 'if' clauses as directives (ICDs) in Finnish and Swedish conversation. We showed that such conditional clauses are responded to by the recipients of the directives in ways which show that they do not wait for a main clause to be produced. This indicates that the ICDs are conventionalized as directives and function as such without projecting a consequent (an apodosis) to emerge. In this sense, insubordinated conditionals are not adverbials at all but independent units in their own right. One important interactional benefit of such ICDs is the optionality of compliance they communicate at face value. By evoking conditionality, ICDs suspend the consequences that the nominated action would have, i.e. they are not verbalized. Such directives are less direct in that they, alike the contents expressed in conditionals, are unasserted and thus leave room for interpretation for the recipient as to the desirability of the proposed action. This kind of conditional indirectness can be seen as an orientation towards the dispreferred nature of many directive actions.

Nevertheless, as we have shown, the emergence of insubordinated 'if' directives is often associated with an orderly sequential pattern that bears a close resemblance to the emergence of ordinary adverbial conditional clauses (protases), followed by a consequent clause functioning as an apodosis. Such sequential trajectories, involving a preface, its potential receipt, the conditional clause, its potential receipt, and a subsequent account or consequent, can be very similar, and in fact emerge online in collaboration between the participants in the conversation in both mundane and institutional settings. We have also demonstrated that in such sequences, the nature of the directive and its function as either a directive or a simple conditional can be ambiguous and is also emergent and worked out in interaction between the participants. Thus, what, in the end, is realized as a specific 
grammatical construction with a certain interactional meaning in a conversation is to a high degree contingent on the reciprocal activities by the interactants and a sufficient degree of intersubjectivity between the parties.

\section{Acknowledgments}

The research reported in this paper was conducted in the Finnish Centre of Excellence in Research on Intersubjectivity in Interaction, based at the University of Helsinki (intersubjectivity.fi). We thank the audience at the colloquium "Adverbial patterns in interaction", organized at the University of Potsdam in September 2014, for their comments on our presentation there and the discussant Paul Hopper for inspiration and advice. We are especially grateful to the organizers of the colloquium and the guest editors of this special issue, Dagmar BarthWeingarten and Oliver Ehmer as well as the two anonymous reviewers for their insightful comments on an earlier version of this paper.

\section{References}

Ahrenberg, L., 1987. Interrogative structures of Swedish. Aspects of the relation between grammar and speech acts. Department of Linguistics, Uppsala University, Uppsala.

Anward, J., 1987. Parameters of institutional discourse. In: Gunnarsson, B-L., Linell, P., Nordberg, B. (Eds.), The construction of professional discourse. Routledge, London, pp. 127-150.

Auer, P., 2005. Projection in interaction and projection in grammar. Text 25 (1), 7-36.

Chevalier, F., 2008. Unfinished turns in French conversation: How context matters. Research on Language and Social Interaction 41 (1), 1-30.

Clancy, P., Akatsuka, N., Strauss, S., 1997. Deontic modality and conditionality in discourse. A cross-linguistic study of adult speech to young children. In: Kamio, A. (Ed.), Directions in functional linguistics. Benjamins, Amsterdam, pp. 19-57.

Curl, T. S., Drew, P., 2008. Contingency and action: a comparison of two forms of requesting. Research on Language and Social Interaction 41 (2), 129-153.

Couper-Kuhlen, E., 2014. What does grammar tell us about action? Pragmatics 24 (3), 623-647.

Couper-Kuhlen, E., Selting, M., 2001. Introducing interactional linguistics. In: Selting, M., Couper-Kuhlen, E. (Eds.), Studies in interactional linguistics. Benjamins, Amsterdam, pp. 1-22. 
Couper-Kuhlen, E., Thompson, S.A., 2009. Conditionality and conversational complaining. Paper given at the Department of Finnish language and literature, University of Helsinki. April 3, 2009.

Dancygier, B., 1998. Conditionals and prediction: time, knowledge and causation in conditional constructions. Cambridge University Press, Cambridge.

D'Hertefelt, S., 2015. Insubordination in Germanic: a typology of complement and conditional constructions. Diss., University of Leuwen.

https://lirias.kuleuven.be/handle/123456789/509450

Ervin-Tripp, S., 1976. Is Sybil there? The structure of some American English directives. Language in Society 5 (1), 25-66.

Evans, N., 2007. Insubordination and its uses. In: Nikolaeva, I. (Ed.), Finiteness: theoretical and empirical foundations. Oxford University Press, New York, pp. $366-431$.

Ford, C. E., 1993. Grammar in interaction. Adverbial clauses in American English conversation. Cambridge University Press, Cambridge.

Ford, C. E., 2004. Contingency and units in interaction. Discourse Studies 6 (1), $27-52$.

Green-Vänttinen, M., 2001. Lyssnaren i fokus: En samtalsanalytisk studie av uppbackningar. [The listener in focus. A conversation analytic study of backchanneling.] Svenska Litteratursällskapet i Finland, Helsinki.

Hakulinen, A., Vilkuna, M., Korhonen, R., Koivisto, V., Heinonen, T.-R., Alho, I. 2004. Iso suomen kielioppi [The Comprehensive Grammar of Finnish.] Suomalaisen Kirjallisuuden Seura, Helsinki.

Hakulinen, A., Sorjonen, M.-L., 2009. Designing utterances for action: Verb repeat responses to assessments in Finnish. In: Haakana, M., Laakso, M., Lindström, J. (Eds.), Talk in interaction: comparative dimensions. Suomalaisen Kirjallisuuden Seura, Helsinki, pp. 124-151.

Helasvuo, M.-L., 2006. Passive - personal or impersonal? A Finnish perspective. In: Helasvuo, M-L., Campbell, L. (Eds.), Grammar from the human perspective. CILT 277. Benjamins, Amsterdam, pp. 233-256.

Kangasharju, H., 1991. Neuvottelu keskusteluna. [Negotiation as conversation.] Helsingin kauppakorkeakoulun julkaisuja B 112, Helsinki.

Kauppinen, A., 1998. Puhekuviot, tilanteen ja rakenteen liitto. [Speech figures, a union of context and structure.] Suomalaisen Kirjallisuuden Seura, Helsinki. 
Koivisto, A., 2015. The Finnish aijaa as a stand-alone response and as a part of a multi-unit turn. Paper given at the symposium on Units in responsive position, Turku, Finland, March 7-8, 2015.

Laury, R., 2012. Syntactically non-integrated jos 'if' conditionals as directives. Discourse Processes 49 (3-4), pp. 213-242.

Laury, R., Lindholm, C., Lindström, J., 2013. Syntactically non-integrated conditional clauses in spoken Finnish and Swedish. In: Havu, E., Hyvärinen, I. (Eds.), Comparing and contrasting syntactic structures. From dependency to quasi-subordination. Société Néophilologique, Helsinki, pp. 231-270.

Lerner, G., 1989. Notes on overlap management in conversation: The case of delayed completion. Western Journal of Speech Communication 53 (2), 167-177.

Lindström, A., 1999. Language as social action. Grammar, prosody, and interaction in Swedish conversation. Uppsala University, Uppsala.

Linell, P., 2014. Interactivities, intersubjectivities and language: on dialogism and phenomenology. Language and Dialogue 4 (2), 165-193.

Matihaldi, H.-L., 1979. Nykysuomen modukset I. Kvalitatiivinen analyysi. [Mood in present-day Finnish. Qualitative analysis.] Acta Universitatis Ouluensis Series B, Humaniora 7, Philologica No. 2, Oulu.

Mithun, M., 2008. The extension of dependency beyond the sentence. Language 84 (1), 264-280.

Ochs, E., Schegloff, E., Thompson, S. (Eds.), 1996. Interaction and grammar. Cambridge University Press, Cambridge.

Pomerantz, A., 1984. Agreeing and disagreeing with assessments: some features of preferred/dispreferred turn shapes. In: Atkinson, J.M., Heritage, J. (Eds.), Structures of social action: studies in conversation analysis. Cambridge University Press, Cambridge, pp. 57-101.

Quirk, R., Greenbaum, S., Leech, G., Svartvik, J., 1985. A comprehensive grammar of the English language. Longman, London.

Sansiñena, M.S., De Smet, H., Cornillie, B., 2015. Between subordinate and insubordinate. Paths toward complementizer-initial main clauses. Journal of Pragmatics 77, 3-19.

Schütz, A., 1953. Commonsense and scientific interpretation of human action. Philosophy and Phenomenological Research 14 (1), pp. 1-38.

Shore, S., 1986. Onko suomessa passiivia. [Does Finnish have a passive?] Suomalaisen Kirjallisuuden Seura, Helsinki. 
Sorjonen, M-L., 2001a. Responding in conversation: A study of response particles in Finnish. Benjamins, Amsterdam.

Sorjonen, M.-L., 2001b. Lääkärin ohjeet. [The doctor's advice.] In: Sorjonen, M.L., Peräkylä, A., Eskola, K. (Eds.), Keskustelu lääkärin vastaanotolla.

[Conversation at the doctor's office.] Vastapaino, Tampere, pp. 89-112.

Sorjonen, M.-L., Raevaara, L., Lappalainen. H., 2009. Mä otan tän. Käynnin syyn esittämisen tavat kioskilla. [I'll take this. Ways to express the reason for the visit to the convenience store.] In: Lappalainen, H., Raevaara, L. (Eds.), Kieli kioskilla. Tutkimuksia kioskiasioinnin rutiineista. [Language at the convenience store.

Studies of the routines in visits to convenience stores.] Suomalaisen

Kirjallisuuden Seura, Helsinki, pp. 90-119.

Stevanovic, M., 2013. Constructing a proposal as a thought: A way to manage problems in the initiation of joint decision-making in Finnish workplace interaction. Pragmatics 23 (3), 519-544.

Suzuki, R., 2009. Interactional profile of causal kara-clause in Japanese conversation: because 'main' clause is not there. Paper given at the $11^{\text {th }}$ International Pragmatics Conference, Melbourne, 12-17 July.

Teleman, U., Hellberg, S., Andersson E., 1999. Svenska Akademins grammatik. [The Swedish Academy Grammar.] Volume 4. Svenska Akademien, Stockholm.

\section{Appendix}

Transcription symbols (cf. Ochs et al. 1996, 461-465) falling intonation

level intonation

slightly falling intonation

?, slightly rising intonation

? $\quad$ rising intonation

$\uparrow \quad$ rise in pitch

en emphasis indicated by underlining

: lengthening of a sound

[ utterances starting simultaneously

] point where overlapping talk stops

(.) micropause, less than 0.2 seconds

(0.5) silences timed in tenths of a second

$><$ talk inside is at a faster pace than the surrounding talk

$<>$ talk inside is at a slower pace than the surrounding talk

en $<$ glottal stop

en- cut off

$=\quad$ "latching", i.e. no silence between two adjacent utterances 
\#en\# creaky voice

"en" altered voice quality

${ }^{\circ} \mathrm{en}^{\circ}$ talk inside is more quiet than the surrounding talk

(en) uncertain transcription

( ) inaudible words

hh audible exhalation (the more h's, the more aspiration)

.hh audible inhalation (length as above)

Glossing abbreviations ${ }^{8}$

ABL ablative

ACC accusative

ADE adessive

ALL allative

CLT clitic

COMP complementizer

COND conditional

COP copula

CMP comparative

DEF definite

DEM demonstrative

DET determiner

ELA elative

ESS essive

FN first name

GEN genitive

GNR generic 3rd person pronoun (cf. 'one')

ILL illative

IMP imperative

INE inessive

INF infinitive

IINF 1st infinitive

LN last name

NEG negation

PAR partitive

PASS passive

PL plural (1PL reads 'first person plural')

PRS present tense

PRT particle

PST past tense

PTC participle

REFL reflexive (pronoun)

SG singular (1SG reads 'first person singular')

TRA translative

Q question clitic

${ }^{8}$ Present tense and nominative case are default for Finnish glossings and are not marked. 
VOC vocative

WH wh-question word 